\title{
THE POTENTIAL OF HYDROGEN LIBERATED FROM METALLIC SURFACES.
}

\author{
BY HARRY NUTTON AND HERBERT DRAKE LAW.
}

\author{
(A Paper read before the Faraday Society on Tuesday, March 19, 1907, \\ Dr. T. M. LOWRY, in the Chair.)
}

During the past few years electrolytic methods of reduction have been gradually introduced, and this has drawn attention to the use of different electrodes. It was recognised long ago by Caspari that the potential of hydrogen liberated from a cathode surface has by no means a fixed value, but varies from metal to metal within fairly wide limits. These early experiments were considerably extended by Tafel, and this investigator was the first to point out the connection between chemical reaction and "supertension." As a result of numerous experiments, the conclusion arrived at was that the reduction of an organic substance proceeds furthest when the potential of the hydrogen bringing about this result is the highest. In this work the metals were arranged in the following order : Mercury, lead, cadmium, tin, silver, bismuth, gold, nickel, platinum (black), the first metal being most capable of bringing about the reduction of a compound not readily attacked, while platinised platinum possessed the property in the lowest degree. Working in an entirely different region of chemistry with inorganic compounds, the effects of metallic impurities on the reducing action of zinc in acid medium were studied by Law and Chapman (Analyst, 1906, 5), and the results of Caspari and Tafel were confirmed, but a difficulty occurred in the case of iron. This latter metal was extremely irregular in its behaviour. Further, it became of interest to fix the relative positions of cadmium and zinc, as these two metals promise to take up a prominent place in analytical chemistry. A little later than this platinum was found to behave in a very curious manner when used in a freshly platinised condition (Law, Trans. Faraday Soc., vol. ii., May, 1906, p. 72), and still later copper, aluminium, and nickel also were found to behave anomalously. Both copper and platinum (black, exhibit a remarkable activity in the reduction of aromatic aldehydes, and iron and aluminium can at times cause a complete resinification of the product. The activity of copper, for example, is seriously affected by external circumstances, and so by the substitution of an alkaline electrolyte for an acid one the abnormal reaction of the first case falls into line with a large class of others. Results similar to these have been obtained by S. Fokin (Zeitschr.f. Elektrochem. 1906, 12, 749), who ascribes the activity to the intermediate formation of metallic hydrides. From considerations such as above it seemed of interest to study the question of supertension under different conditions, in the hope of being able to pick out the purely chemical from the physical effects. The conclusions previously arrived at may be briefly summarised in the following: With an organic compound resinification can take place wherever a double link exists. The effect of the supertension is to produce the largest amount of resinous matter when the highest potential is 
used. Bearing these facts in mind, it is possible to explain many apparent anomalies. The reduction of oleic acid to stearic acid takes place better on copper and nickel cathodes (loc. cit.) than on lead (Petersen, Zeitschr. f. Elektrochem. 1906, II, 549), in spite of the greater E.M.F. in the case of the latter metal. This is due to the resin formation which clogs the cathode, while with nickel the potential never rises high enough to form these complex compounds. In the reduction of benzaldehyde in acid solution the reaction proceeds far more quickly on copper cathodes than on lead. Here it is possible to follow the reaction. At first the lead is most vigorous, but as the resin increases in quantity the velocity falls far behind that of copper (Law, Trans. Chem. Soc. 1906, 89, 1524), and finally the reduction ceases altogether. Another phenomenon often met with in the case of metallic electrodes is that the reduction of a substance does not set in immediately after starting the current, but only after the elapse of some considerable time. This is very noticeable in the case of iron and nickel, and to a smaller extent with tin. The interpretation is simple, as is shown by the experiments with these metals. The supertension is by no means a fixed quantity, and is influenced very considerably by the physical condition of the metallic surface of the cathode within wide limits. Very small quantities of impurities exercise a large and varying influence, which is overcome only on long standing in contact with the electrolyte. A cathode then, working below its normal value as a reducing agent, also shows an E.M.F. less than usual. On standing in contact with the electrolyte the condition of the electrode surface gradually becomes readjusted, and the reducing power is recovered. It has already been shown that metallic impurities and other such influences can be overcome by the chemical deposition of small quantities of such metals as cadmium (loc. cit.) on the reducing surface. To confirm the use of such a process by physical measurements the experiments with cadmium deposited electrolytically on platinum were undertaken. The result proves conclusively that a complete cover can be deposited only when the greatest care is taken to obtain a compact, non-crystalline deposition, which bears out what has previously been stated (loc. cit.) in connection with zinc in the reduction of arsenious oxide.

The above refers to physical conditions, but chemical changes are equally effective in bringing about an entire modification of the course of the reduction. This is seen best in the case of copper cathodes. With this metal the reduction of benzaldehyde in alkaline solution proceeds simply and smoothly to a mixture of hydrobenzoins according to the following equation :-

$$
{ }_{2} \mathrm{C}_{6} \mathrm{H}_{5} \cdot \mathrm{CHO}+2 \mathrm{H}=\mathrm{C}_{6} \mathrm{H}_{5} \cdot \mathrm{CH}(\mathrm{OH}) \cdot \mathrm{CH}(\mathrm{OH}) \cdot \mathrm{C}_{6} \mathrm{H}_{5} \text {. }
$$

The E.M.F. of the cathode is lowered about 0.2 volt on the addition of 5 grams of the aldehyde. Very little resin is formed. With sulphuric acid as electrolyte the product is entirely different, and the reaction proceeds further, benzyl alcohol being the product-

$$
\mathrm{C}_{6} \mathrm{H}_{5} \cdot \mathrm{CHO}+2 \mathrm{H}=\mathrm{C}_{6} \mathrm{H}_{5} \cdot \mathrm{CH}_{2} \mathrm{OH} \text {. }
$$

Small quantities of hydrobenzoin make their appearance, and only the most minute traces of resin. At the same time the fall of E.M.F. on the addition of 5 grams of the depolariser is quite absent, and in some cases an actual rise was registered. From this it is quite evident that a change of E.M.F. due to the addition of a depolariser gives no indication of the vigour of a chemical reaction. Still more curious than this is the influence of temperature. The 
above experiment was conducted at $10^{\circ}$, but on repeating at $40^{\circ}$ the benzyl alcohol formation was almost absent in the acid solution, and a good yield of hydrobenzoin was oblained. Thus at the higher temperature the least chemical reaction took place. Experiments conducted in this direction showed that the E.M.F. gave no indication of such a change as this. The phenomenon was entirely chemical. Throughout the whole of this work the formation of resistance films on the surface of the cathodes was noticed. In the case of iron and aluminium these might be classed under the head of passivity, but it is almost impossible to explain them completely on the assumption of an oxide film. They are present in the same marked degree with smooth platinum, mercury, and magnesium, and were absent only in the cases of roughened nickel, platinum, copper, and lead. In some cases this was due to the formation of a film of hydrogen on the surface of the cathode, but the cause of this is quite unknown.

The conclusion arrived at may be briefly stated as follows : The supertension of one and the same metal is by no means a fixed quantity. It is influenced by the physical and chemical nature of the surface within wide limits. Film formations also have a large influence. Chemical reactions, such as the formation of resins, are greatly increased by raising the supertension, but these complex bodies may totally hide any other chemical reaction.

The nature of the electrolyte can completely change the chemical reaction without any corresponding change in the supertension.

The supertension gives small indication of catalytic action. The fall of potential on adding a depolariser is only a rough guide of the nature of the reduction taking place. The small drop of E.M.F. in the case of copper and platinised platinum may be an indication of catalysis.

Method.-In this work a porous pot of a capacity of 120 c.c. was used to contain the cathode, the volume of solution being roo c.c. After being carefully cleaned it was fitted with a trebly bored rubber stopper. Short pieces of glass tubing were fitted into two of the holes, one serving as a gas outlet and the other for fixing the cathode. The third hole contained a capillary tube. The cathode was fixed in position by means of sealing wax, and could be readily removed. The capillary tube was bent at right angles inside the porous pot, and was plugged with filter paper. This was pressed close to the inside of the cylindrical cathode, and was connected with the hydrogen electrode. The anode compartment was a stout glass jar containing a spiral platinum wire as anode. This apparatus was connected in series with twelve storage cells, an adjustable resistance, and a standard millivoltmeter shunted to read milliamperes.

The E.M.F. between the cathode and the hydrogen electrode was measured on the Clark-Fisher "Compensating Potentiometer," reading to $\frac{1}{10}$ millivolt. When possible the cathodes were bent in the form of a cylinder, and had a superficial area of 20 sq. $\mathrm{cms}$. on one side. The current in each case was started at the lowest reading, and measurements taken after an almost steady state had been arrived at.

It has been pointed out by Tafel that in most cases the E.M.F. of the cathode gradually increases with a constant current, and reaches a maximum sometimes after several hours. The rise is, however, very rapid at first, and after half an hour increases very slowly. When this condition was reached the measurement was made and the current adjusted for the next reading.

These results are shown in the form of curves, the abscissæ being the E.M.F. measured-the supertension-and the ordinates represent the current in amperes and the current density in amperes per sq. $\mathrm{cm}$. 
Copper.-These electrodes were cut from a sheet of electrolytic copper and cleaned with nitric acid. To ensure purity, a clean metallic surface was deposited electrolytically in several cases, but the results were in nowise altered. With such electrodes the following results were obtained :-

TABLE I

Copper in 5 per cent. Sulphuric Acid.

\begin{tabular}{|c|c|c|c|c|}
\hline \multirow{3}{*}{$\begin{array}{c}\text { (1) } \\
\text { Current Density } \\
\text { in Amperes } \\
\text { per sq. cm. }\end{array}$} & \multicolumn{4}{|c|}{ E.M.F. IN VoLts. } \\
\hline & (2) & (3) & (4) & (5) \\
\hline & $5 \% \mathrm{H}_{2} \mathrm{SO}_{4}$. & $\begin{aligned} 5 \% \mathrm{H}_{2} \mathrm{SO}_{4} \\
50 \% \text { Alcohol. }\end{aligned}$ & $\begin{array}{c}5 \% \mathrm{H}_{2} \mathrm{SO}_{4} \\
50 \% \% \mathrm{Alchol}^{2} \\
6.6 \% \\
\mathrm{C}_{6} \mathrm{H}_{5} \mathrm{CHO}\end{array}$ & $\begin{array}{c}5 \% \mathrm{H}_{2} \mathrm{SO}_{4} \\
50 \% \mathrm{Alcohol} \\
0.0002 \mathrm{gm} \text {. PtCl }\end{array}$ \\
\hline 0.0005 & 0.3342 & $0 * 308 \mathrm{I}$ & 0.3209 & 0.0377 \\
\hline 0.0007 & 0.3509 & 二 & $0.33^{62}$ & E \\
\hline $\begin{array}{l}0.0008 \\
0.001\end{array}$ & $\begin{array}{l}0.3618 \\
0.3663\end{array}$ & $0 \cdot 3264$ & 0.3555 & 0.0537 \\
\hline 0'00I5 & 0.3827 & - & 0.3723 & - \\
\hline 0.003 & 0.4083 & 0.4115 & 0.4037 & 0.0786 \\
\hline 0.005 & 0.4245 & 0.4310 & 0.4249 & 0.0906 \\
\hline 0.01 & 0.4530 & 0.4600 & 0.4527 & O.IIO4 \\
\hline 0.025 & - & $0 * 4966$ & - & 0.1517 \\
\hline 0.05 & 0.5287 & 0.5277 & 0.5260 & 0.2002 \\
\hline
\end{tabular}

It has been suggested in a recent Paper that the activity of copper as a cathode is due to an intermediate hydride formation. This being so, it might be expected that for a constant current density the E.M.F. would rise gradually until the hydrogen absorption should be complete. This is exactly what does take place, but the addition of benzaldehyde as a depolariser has only a very small effect on the supertension (4), although a very vigorous chemical action takes place. In some cases even the cathode potential was increased, and this may indicate that some catalytic action is taking place on the metallic surface due to an unknown property of the copper. The absence of resinous matter serves to keep this action unimpaired throughout an experiment. It is quite probable that hydrides of copper are formed, but it is difficult to see how these can take any direct part in the reduction of benzaldehyde. Very similar to this, Tafel has already quoted a case where the supertension of lead is slightly increased in the presence of a depolariser, although no hydride formation is possible here. As a rule the potential of copper is slightly decreased on the addition of alcohol for the same amount of polarisation ( 2 and 3 ). No. 3 does not show this phenomenon with the higher values, as the polarisation was continued for some considerable time. As the maximum E.M.F. is not reached immediately, it is quite possible that these values are slightly low, due to incomplete polarisation. This point we are at present investigating. In the last column (5) the effect of a very small addition of platinum chloride is seen. This explains the inefficiency of electrodes which have long been in use without being cleaned, and has been shown in a previous Paper (loc. cit.). 
TABLE II.

Copper in Potassium Hydroxide.

\begin{tabular}{|c|c|c|}
\hline \multirow{3}{*}{$\begin{array}{l}\text { (1) } \\
\text { Current Density } \\
\text { in Amperes } \\
\text { per sq. cm. }\end{array}$} & \multicolumn{2}{|c|}{ E.M.F. IN Vol.rs. } \\
\hline & (2) & (3) \\
\hline & $\begin{array}{c}5 \% \text { KOH. } \\
50 \% \text { Alcohol. }\end{array}$ & $\begin{array}{c}5 \% \text { KOH. } \\
50 \% \text { Alcohol. } \\
6.6 \% \mathrm{C}_{6} \mathrm{H}_{5} \mathrm{CHO} .\end{array}$ \\
\hline 0.0005 & 0.4072 & 0.2285 \\
\hline 0.0007 & 0.4343 & 0.2372 \\
\hline 0.0009 & 0.4521 & 0.2422 \\
\hline 0.001 & 0.4575 & 0.2444 \\
\hline 0.0015 & 0.4743 & 0.2570 \\
\hline 0.003 & 0.5000 & 0.2607 \\
\hline 0.005 & 0.5146 & 0.2682 \\
\hline 0.0075 & 0.5273 & $0.275^{2}$ \\
\hline 0.05 & 0.5934 & 0.3634 \\
\hline
\end{tabular}

In this case also the E.M.F. was lowered slightly on the addition of alcohol, but benzaldehyde made a very considerable change not observed in sulphuric acid solutions. The product of reduction was hydrobenzoin, but in the previous case it was chiefly benzyl alcohol; that is, the drop in the E.M.F. is greatest where least chemical action takes place, while the reverse was expected. It is quite unlikely that the presence of alkali prevents the formation of an intermediate hydride of copper, and as a consequence we are quite unable to explain this seemingly anomalous behaviour. In the case of both alkaline and acid solutions the resin formation was almost absent. This is entirely a property of reduction processes at a low potential even when unsaturated carbon atoms are present.

These values by no means represent the maximum E.M.F., measurements being made when the continued rise became small. In this case also the addition of alcohol lowered the supertension, but this again might have been due to insufficient polarisation. With benzaldehyde quite a large fall of E.M.F. was noticed quite different from the case of copper. The product of the reaction contained in the case of platinum far more resin and less benzyl alcohol than in the case of the previous experiments. The gradual rise of cathodic potential for a constant current density probably indicated the slow formation of a metallic hydride. This might even become supersaturated with hydrogen, the smooth formation of the surface and the consequent greater surface tension preventing the ready liberation of the absorbed gas.

Platinum, Polished, in Potassium Hydroxide.-These results differ only very slightly from those obtained with acid solutions. There was, however, a marked difference in the product of reduction. The resin formation was very small, but not entirely absent, and an almost theoretical yield of hydrobenzoin resulted. It is quite evident, therefore, that the constitution of the solvent has a very decided influence on reduction processes quite independent of the supertension. On the addition of alcohol the polarisation was allowed to continue for some time before making any measurements (2). This caused the E.M.F. to rise above that obtained without alcohol, but as the current density was increased the value gradually fell below that obtained in (3). This seems to prove that the polarisation takes place more slowly 
TABLE III.

Polished Platinum in Potassium Hydroxide.

\begin{tabular}{|c|c|c|c|c|}
\hline \multirow{3}{*}{$\begin{array}{l}\text { (1) } \\
\text { Current Density } \\
\text { in Amperes } \\
\text { per sq. cm. }\end{array}$} & \multicolumn{3}{|c|}{ E.M.F. IN VoLTS. } & \multirow{3}{*}{$\begin{array}{c}\text { (5) } \\
5 \% \mathrm{H}_{2} \mathrm{SO}_{4} \\
50 \% \mathrm{Alcohol} \\
6.6 \% \mathrm{C}_{6} \mathrm{H}_{5} \mathrm{CHO} .\end{array}$} \\
\hline & (2) & (8) & (द) & \\
\hline & $5 \% \mathrm{KOH}$. & $\begin{array}{l}5 \% \text { KOH. } \\
50 \% \text { Alcohol. }\end{array}$ & $\begin{array}{c}5 \% \text { KOH. } \\
50 \% \text { Alcohol. } \\
6.6 \% \mathrm{C}_{6} \mathrm{H}_{5} \mathrm{CHO} .\end{array}$ & \\
\hline 0.0005 & $0: 2031$ & 0.2505 & 0.1838 & $0 \cdot 1087$ \\
\hline 0.0007 & 0.2303 & 0.2811 & 0.2193 & 0.1217 \\
\hline 0.0009 & $0^{\prime} 2508$ & 0.2897 & 0.2367 & O.1295 \\
\hline $0^{\circ} \mathrm{OOI}$ & 0.2624 & 0.3089 & 0.2448 & 0.1325 \\
\hline $0^{\circ} 0015$ & 0.3078 & $0: 3493$ & 0.2825 & - \\
\hline 0.005 & $0: 3993$ & 0.4267 & 0.3225 & $0 \cdot 1862$ \\
\hline O०OI & 0.4567 & 0.4677 & $0.355^{2}$ & - \\
\hline o'or5 & - & - & 0.3852 & - \\
\hline 0.025 & 0.5352 & 0.5203 & $0^{\prime} 4283$ & - \\
\hline 0.05 & 0.6038 & 0.5608 & $0.493 I$ & 一 \\
\hline
\end{tabular}

in alcoholic solutions than in those containing only dilute alkali. It is not unlikely that this phenomenon is due to the difference in viscosity of the two solutions. The measurements tabulated under (4) were made very slowly, to allow the E.M.F. to rise to its highest value. The value obtained still remained considerably below that without the aldehyde, and in nowise resembled the result obtained with copper in acid solutions.

Platinum, Platinised.-It has already been shown by one of us (loc. cit.) that freshly prepared platinum behaves quite differently from electrodes which have been in use for some time. It became necessary, therefore, to decide whether this was due to a difference in the supertension. The electrodes were prepared and subjected to varying conditions. One, for example, was polarised for I2 hours at the anode, while a second was given a similar treatment at the cathode, but in each case the resulting E M.F. did not vary to any considerable extent.

TABLE IV.

Platinised Platinum in Sulphuric Acid.

\begin{tabular}{|c|c|c|c|c|c|}
\hline & \multicolumn{5}{|c|}{ E.M.F. IN VoLTS. } \\
\hline (1) & (2) & (3) & (4) & (5) & (6) \\
\hline $\begin{array}{l}\text { Current Density } \\
\text { in Amperes } \\
\text { per sq. cm. }\end{array}$ & $5 \% \mathrm{H}_{2} \mathrm{SO}_{4}$ & $\begin{array}{r}5 \% \mathrm{H}_{2} \mathrm{SO}_{4} \\
50 \% \text { Alcohol. }\end{array}$ & $\begin{array}{r}5 \% \mathrm{H}_{2} \mathrm{SO}_{4} \\
5 \mathrm{O} \% \text { Alcohol. } \\
6.6 \% \mathrm{C}_{6} \mathrm{H}_{5} \mathrm{CHO} .\end{array}$ & $\begin{array}{r}5 \% \\
50 \% \text { Alcohol. }\end{array}$ & $\begin{array}{r}5 \% \mathrm{H}_{2} \mathrm{SO}_{4 \cdot} \\
50 \% \mathrm{Allohhol}^{2} \\
6.6 \% \mathrm{C}_{6} \mathrm{H}_{5} \mathrm{CHO} \text {. }\end{array}$ \\
\hline 0.0005 & 0.0103 & - & - O.II40 & - & -0.0795 \\
\hline 0.001 & 0.0148 & 0.0045 & -0.0900 & - & - \\
\hline 0.0015 & - & - & - & 0.0077 & - \\
\hline 0.002 & - & - & -0.0687 & - & - \\
\hline 0.003 & 0.0232 & 0.0163 & - & - & - \\
\hline 0.005 & 0.0273 & $0.026 \mathrm{r}$ & -0.0377 & 0.0249 & -0.0524 \\
\hline 0.01 & 0.0349 & 0.0461 & -0.0045 & 0.0472 & $-0.024 \mathrm{I}$ \\
\hline 0.025 & - & - & - & 0.1129 & +0.0219 \\
\hline \multirow[t]{2}{*}{0.05} & 0.0890 & 0.1715 & + 0.1694 & 0.2282 & +0.0699 \\
\hline & \multicolumn{3}{|c|}{ I. } & \multicolumn{2}{|c|}{ II. } \\
\hline
\end{tabular}


In the first set of experiments $(2,3,4)$ a cathode which had been in use for several experiments was used. It was not active, and no longer reduced benzaldehyde to any considerable extent. The maximum E.M.F. was reached far more rapidly than in the previous case, the rise on continuing the experiment with a constant current density being very small. If a hydride of platinum is formed its supertension is not much higher than that of platinum itself. Here the supertension phenomenon is not marked as in the case of polished platinum, due no doubt to the roughened surface of the metal. The addition of alcohol in this case $(2,3)$ caused a slight increase in the E.M.F. with the higher current densities. The fall of the voltage on adding benzaldehyde was great only where low-current densities were employed, and increased rapidly as the current density was made greater (4). In $(5,6)$ the same cathode was used, but was polarised for I 2 hours at the anode. The E.M.F. differed only slightly in alcoholic solutions, but on the addition of benzaldehyde the voltage fell and did not rise again to the previous value.

In another set of experiments, which are not recorded, the same electrode was employed, but $\mathrm{KOH}$ was substituted for $\mathrm{H}_{2} \mathrm{SO}_{4}$. The results were practically the same as in V. until benzaldehyde was added, and the E.M.F. fell as in experiment 6.

Nickel.-The results obtained with this metal varied somewhat with different samples. In the first set of experiments the cathode was soft and readily soluble in nitric acid. As it dissolved the surface remained smooth and did not appear crystalline. In the second case the nickel employed was dull in appearance, and was almost insoluble in cold nitric acid. At higher temperatures it dissolved slowly, but still remained dull in appearance and crystalline.

\section{TABLE V.}

Nickel in Potassium Hydroxide.

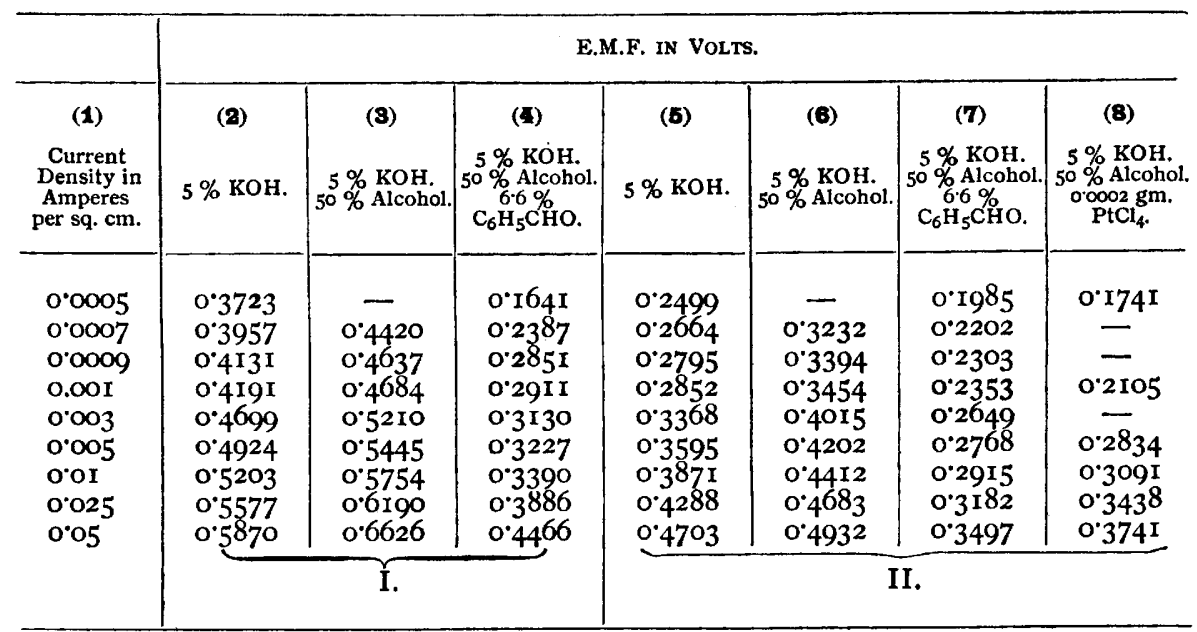

In set I. with the soft nickel the E.M.F. was increased by the addition of alcohol (3), but this was due to the longer polarisation, the maximum 
supertension not being reached immediately. In (6) the addition of alcohol was not so marked as in the previous case, but the supertension remained persistently below those of set I. This result was not due to metallic impurity, for the analysis showed that each was almost pure and contained only a trace of copper. Further, the addition of platinum chloride (8) to the cathode solution had only a relatively small effect on the supertension. It

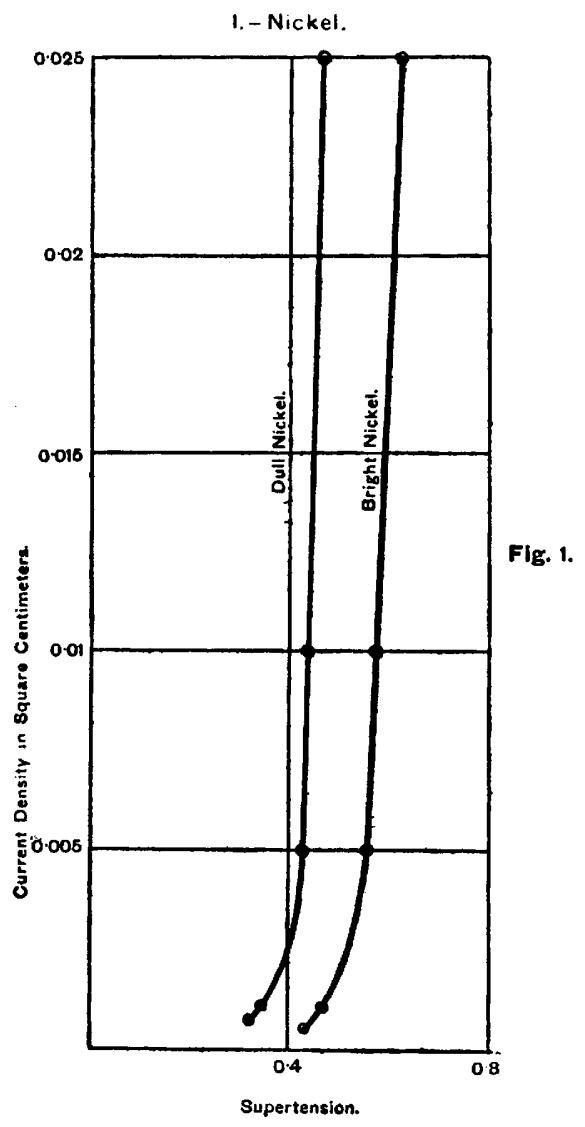

was due then to the structure of the metallic surface, and corresponds to platinum, which shows an even more remarkable change. In another experiment the E.M.F. was even lower than in the one recorded, and in this case the reduction took place very slowly, and reached a normal value only after polarisation for some hours. The product of reaction was then the same as in the previous cases, and consisted of almost pure hydrobenzoin. 
TABLE VI.

Tin in Sulphuric Acid.

\begin{tabular}{|c|c|c|c|c|c|c|c|}
\hline \multirow{3}{*}{$\begin{array}{c}\text { (1) } \\
\text { Current } \\
\text { Density in } \\
\text { Amperes } \\
\text { per sq. cm. }\end{array}$} & \multicolumn{7}{|c|}{ E.M.F. IN VoLTs. } \\
\hline & (2) & (3) & (4) & (5) & (6) & (7) & (8) \\
\hline & $\begin{array}{l}5 \% \mathrm{H}_{2} \mathrm{SO}_{4} \\
50 \% \text { Alcohol. }\end{array}$ & $5 \% \mathrm{H}_{2} \mathrm{SO}_{4}$ & $5 \% \mathrm{H}_{2} \mathrm{SO}_{4}$ & $\begin{array}{c}5 \% \mathrm{H}_{2} \mathrm{SO}_{4} \\
50 \% \% \mathrm{Alcohol} \\
0.002 \mathrm{gm} . \\
\mathrm{PtCl}_{4}\end{array}$ & $\begin{array}{c}5 \% \mathrm{H}_{2} \mathrm{SO}_{4} \\
50 \% \mathrm{Alcohol} \\
\text { \%ol gm. } \\
\text { CuSO } \\
\text { Cus. }\end{array}$ & $\begin{array}{c}5 \% \mathrm{H}_{2} \mathrm{SO}_{4} \\
50 \% \text { Alcohol. } \\
\text { o. or gm. } \\
\mathrm{NiSO}_{4} .\end{array}$ & $\begin{array}{c}5 \% \mathrm{H}_{2} \mathrm{SO}_{4 .} \\
50 \% \% \text { Alcohol. } \\
6 \% \% \\
\mathrm{C}_{6} \cdot 6 \mathrm{H} 5 \mathrm{CHO} .\end{array}$ \\
\hline 0.0005 & $0 \cdot 5287$ & 0.6249 & 0.6407 & 0.2621 & 0.3856 & 0.4942 & 0.4595 \\
\hline 0.0007 & - & 0.6459 & 0.6627 & - & & - & 0.4708 \\
\hline 0.001 & 0.5624 & 0.6587 & 0.6857 & 0.2948 & 0.4192 & $0.525 \mathrm{I}$ & $0: 4856$ \\
\hline 0.003 & & 0.7026 & 0.7426 & - & - & 0.5709 & 0.5301 \\
\hline 0.005 & 0.6383 & 0.7220 & 0.7694 & 0.3726 & 0.4918 & $0.593^{8}$ & 0.5580 \\
\hline $0 \circ \mathrm{OI}$ & 0.6722 & $0 \div 7784$ & $0.807 \mathrm{I}$ & $0 \% 4107$ & 0.5318 & 0.6451 & 0.6041 \\
\hline 0.025 & 0.7211 & 0.8367 & 0.8892 & 0.4632 & 0.5945 & 0.6703 & 077000 \\
\hline $0 \circ 05$ & 0.7611 & 0.9000 & 0.9882 & 0.5080 & 0.6630 & 0.7113 & o:7976 \\
\hline
\end{tabular}

The tin used in these experiments contained small traces of metallic impurities. The addition of alcohol made a small difference to the result, about the same as in alkaline solutions, and, as before, a maximum E.M.F. was not reached immediately. In experiment 2 a freshly cut electrode was used, but the resulting supertension was considerably below that obtained by Tafel, although the polarisation was continued for some considerable time. This electrode was left standing overnight in the acid solution, and during that time it had become very dull in appearance. The experiment was then repeated, and recorded in 3 and 4 . The supertension had now risen very considerably, and was practically the same as that measured by Tafel. This was caused, apparently, by the formation of a pure metallic surface. It is an example of self-preparation, and is caused probably by inequalities of solution tension of different parts of the surface, i.e., by the formation of small couples and the consequent deposition of an even surface over the electrode. This action may be aided by the presence of atmospheric oxygen.

The addition of impurities lowered the supertension considerably, and was greatest with platinum. This later metal is not found in commercial tin, but iron and copper are, and it became of interest, therefore, to determine the influence of these substances on a pure tin surface. In the case of copper small additions produced a very marked fall of E.M.F., but with iron a slight increase was observed in the supertension when a decrease was expected. This extremely curious result illustrates the interesting behaviour of iron, and will be further demonstrated later. Small additions of nickel had the effect of lowering the supertension somewhat. 
LIBERATED FROM METALLIC SURFACES

TABLE VII.

Tin in Potassium Hydroxide.

\begin{tabular}{|c|c|c|c|c|c|}
\hline \multirow{3}{*}{$\begin{array}{c}\text { (1) } \\
\text { Current Density } \\
\text { in Amperes } \\
\text { per sq. cm. }\end{array}$} & \multicolumn{5}{|c|}{ E.M.F. IN VolTs. } \\
\hline & (2) & (8) & (4) & 5) & (6) \\
\hline & $5 \%$ кон. & $\begin{array}{c}5 \% \text { KOH. } \\
50 \% \text { Alcohol. }\end{array}$ & $\begin{array}{c}5 \% \text { KOH. } \\
50 \% \text { Alcohol. } \\
0^{\circ 0002} \mathrm{gm} . \mathrm{PtCl}_{4} .\end{array}$ & $\begin{array}{l}5 \% \text { KOH. } \\
50 \% \text { Alcohiol. } \\
\text { o.01 } \text { gm. CuSO }_{4} \text {. }\end{array}$ & $\begin{array}{c}5 \% \text { KOH. } \\
50 \% \text { Alcohol. } \\
6 . \% \mathrm{C}_{6} \mathrm{H}_{5} \mathrm{CHO} .\end{array}$ \\
\hline 0.0005 & 0.6084 & 0.5403 & 0.2920 & 0.4905 & 0.2560 \\
\hline 0.001 & 0.6515 & 0.5963 & 0.3393 & 0.5273 & 0.2783 \\
\hline $0^{\circ} 005$ & 0.7775 & 0.7316 & 0.4069 & 0.6047 & 0.3293 \\
\hline O०OI & 0.8289 & 0.7881 & 0.4364 & $0.640 \mathrm{I}$ & 0.3657 \\
\hline $0^{\circ} 025$ & 0.9035 & $0.85^{89}$ & 0.4866 & o.6919 & 07764 \\
\hline 0.05 & 09575 & 0.9130 & $0^{\circ} 528 \mathrm{I}$ & $0.73^{86}$ & 0.8717 \\
\hline
\end{tabular}

In alkaline solutions the fall of E.M.F. was rather greater on the addition of alcohol than in acid solutions (3). The increase of i supertension on allow-

11. Tin. in $\mathrm{KOH}$ and Aloohol.

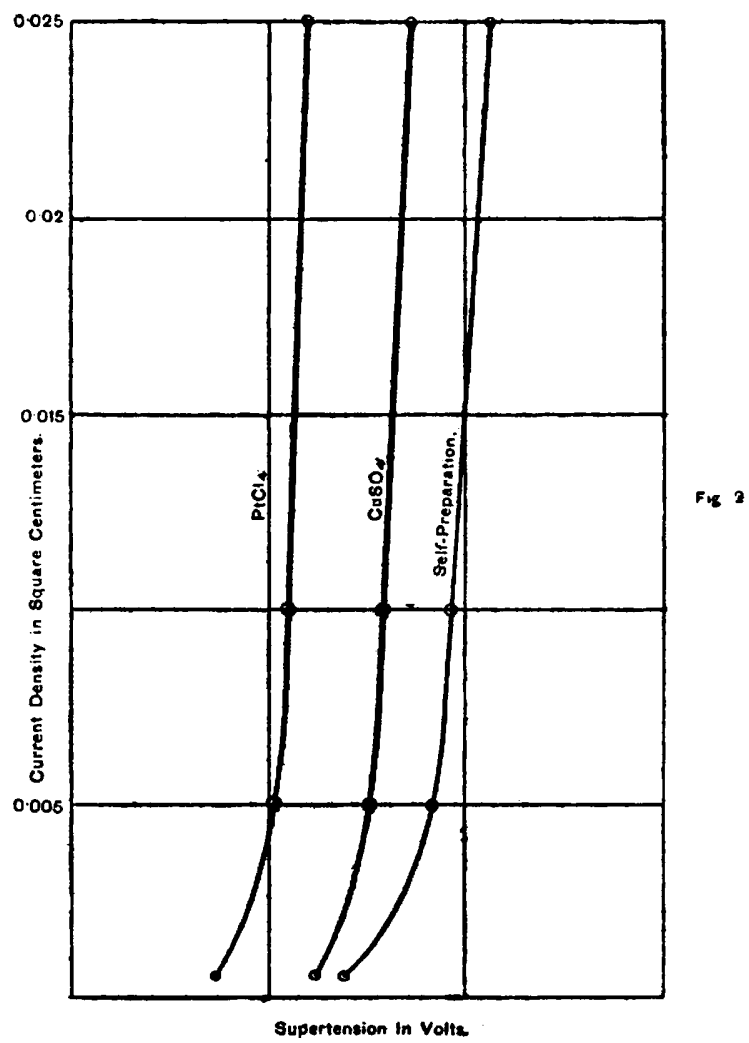

ing the metal to stand overnight in contact with the electrolyte was not as great as in the previous case, but was still observed (2). The effect of 
metallic impurities was very marked, but not as great as in acid solutions In this case the addition of small quantities of iron did not increase the E.M.F., but lowered it slightly.

The behaviour of benzaldehyde is very curious in this case. As the current increases the E.M.F. rises continually, and continues to rise slowly for a constant current density. When this latter reaches 0.002 amperes per sq. cm., and the E.M.F. $0_{5} 5$ volt, the rise in the supertension becomes very rapid. This was caused probably by the formation of a resin on the cathode, and when the latter was removed it was found to be covered with a thin coating of a sticky substance. On the other hand, it may be due to the rapid

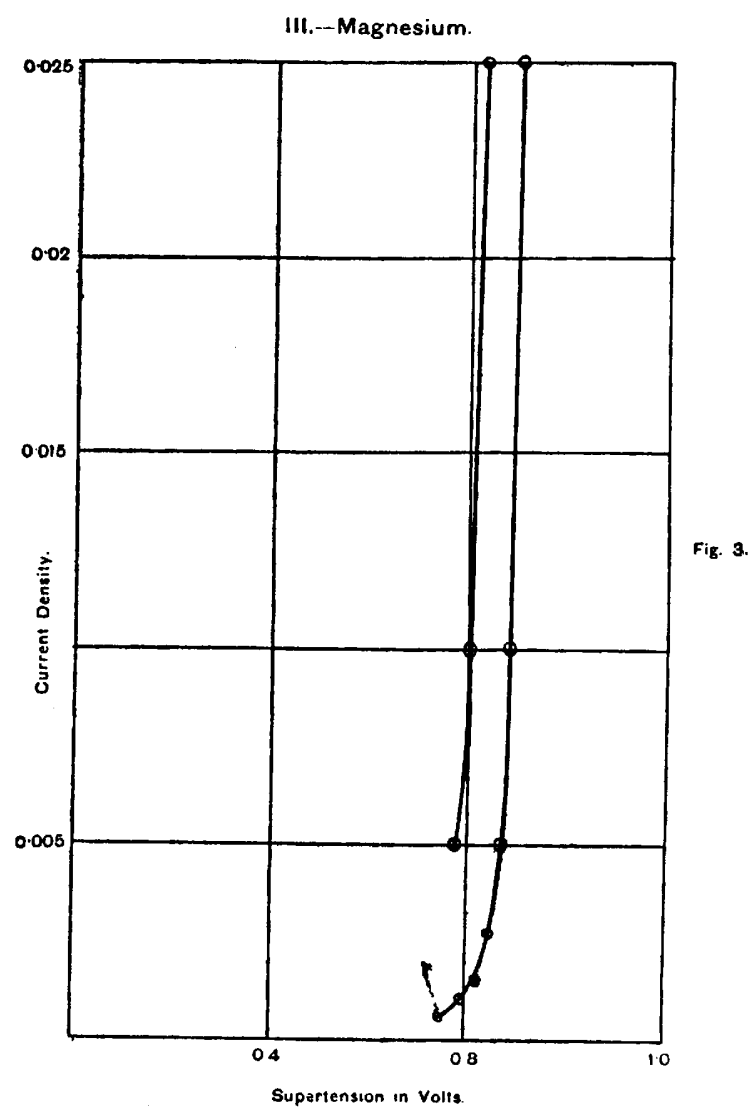

removal of benzaldehyde round the cathode by reduction, leaving a neighbouring layer free from depolariser. In acid solutions the rise of E.M.F. in the presence of benzaldehyde was a more gradual process, ${ }_{4}$ no very sudden rise being observed. In these latter solutions the resin formation takes place very readily, and is formed probably at the very lowest E.M.F. in sufficient quantity to raise the supertension to its maximum value soon after the start. The rise of E.M.F. due to films in other cases will be seen later.

Magnesium in Potassium Hydroxide.-The electrode was made from an ingot of pure electrolytic magnesium.

In this case it was difficult to obtain concordant results. With a perfectly 
LIBERATED FROM METALLIC SURFACES

TABLE VIII.

Magnesium in Potassium Hydroxide.

\begin{tabular}{|c|c|c|}
\hline & \multicolumn{2}{|c|}{ E.M.F. IN VOLTS. } \\
\hline (1) & (2) & (3) \\
\hline $\begin{array}{l}\text { Current Density in } \\
\text { Amperes per sq. } \mathrm{cm} .\end{array}$ & $5 \%$ кон. & $5 \%$ кон. \\
\hline 0.0005 & $0^{\circ} 734^{\circ}$ & 一 \\
\hline $0^{\circ} \mathrm{OOI}$ & $0^{\circ} 793^{\circ}$ & 一 \\
\hline 0.0015 & 0.8170 & 一 \\
\hline $0^{\circ} 003$ & $0.847 \mathrm{I}$ & - \\
\hline 0.005 & 0.8655 & $0^{\circ} 7757$ \\
\hline O०OI & 0.8868 & 0.8022 \\
\hline 0.025 & 0.8950 & 0.8287 \\
\hline 0.05 & 0.93 I 8 & 0.8571 \\
\hline
\end{tabular}

clean magnesium electrode the readings given in experiment 2 were determined. On long polarisation, however, much lower results were obtained (3) ; thus after the lapse of 2 hours the readings shown in (3) resulted. Very high values may, however, be obtained, and in one case the E.M.F. rose to 3 volts at $\mathrm{I}$ ampere, but immediately began to fall. This fall is by no means rapid, and takes place over a period of several hours.

At present we cannot offer any complete explanation of this phenomenon. It is evident, however, that some resistance film is set up, but at present we cannot tell the exact nature of this.

TABLE IX.

Iron in Potassium Hydroxide.

\begin{tabular}{|c|c|c|c|c|}
\hline \multirow{3}{*}{$\begin{array}{c}\text { (1) } \\
\text { Current Density } \\
\text { in Amperes } \\
\text { per sq. } \mathrm{cm} .\end{array}$} & \multicolumn{4}{|c|}{ E.M.F. IN VOLTS, } \\
\hline & (2) & (3) & (4) & (5) \\
\hline & $5 \%$ кон. & $\begin{array}{l}5 \% \text { KOH. } \\
50 \% \text { Alcohol. }\end{array}$ & $\begin{array}{l}5 \% \text { KOH. } \\
5 \% \text { Alcohol. }\end{array}$ & $\begin{array}{c}5 \% \text { KOH. } \\
50 \% \text { Alcohol. } \\
6.6 \% \mathrm{C}_{6} \mathrm{H}_{5} \mathrm{CHO} .\end{array}$ \\
\hline 0.0005 & $0^{\prime} 1480$ & o. I6I 5 & O'I992 & $0^{\circ} 213 \mathrm{I}$ \\
\hline 0.001 & $0^{*} 174 \mathrm{I}$ & $0^{\circ} 2000$ & 0.2407 & 0.2905 \\
\hline 0.0015 & 0.1925 & 0.2234 & 0.2646 & $0.348 \mathrm{I}$ \\
\hline $0^{\circ} 003$ & 0.2232 & 0.2368 & 0.3030 & $0: 4727$ \\
\hline 0.005 & $0: 2496$ & 0.2761 & 0.3335 & 0.5146 \\
\hline $\mathrm{O}^{\circ} \mathrm{OI}$ & $0 \cdot 2947$ & 0.4188 & 0.3782 & 0.5287 \\
\hline 0.025 & $0 \cdot 3795$ & 0.6869 & 0.4348 & 0.6473 \\
\hline 0.05 & $0: 4470$ & o.9947 & $0.476 \mathrm{I}$ & 0.7906 \\
\hline
\end{tabular}

The chemical nature of the products of reduction varied very considerably even with the same iron cathode, and depended very largely on the previous treatment of the metal. Thus a piece of soft sheet iron containing a little carbon was almost incapable of reducing benzaldehyde, but on being allowed to stand in caustic potash solution for some days the reaction proceeded quite normally, hydrobenzoin being the product.

This same electrode was heated in a Bunsen burner, and on then being 
treated with nitric acid it dissolved very slowly. On being used as a cathode large quantities of resin were produced, which was not the case in the previous experiments. The first measurements were made with sheet iron which had been heated in a Bunsen burner and allowed to stand in potassium hydroxide solution to prevent rusting (2).

The E.M.F. was low throughout.

In the next experiment (3) the solution contained an addition of alcohol, and the E.M.F. rose to that of lead; on allowing the current to pass for some time these values began to decrease. The current was cut off and the supertension was redetermined after standing for 12 hours in potassium

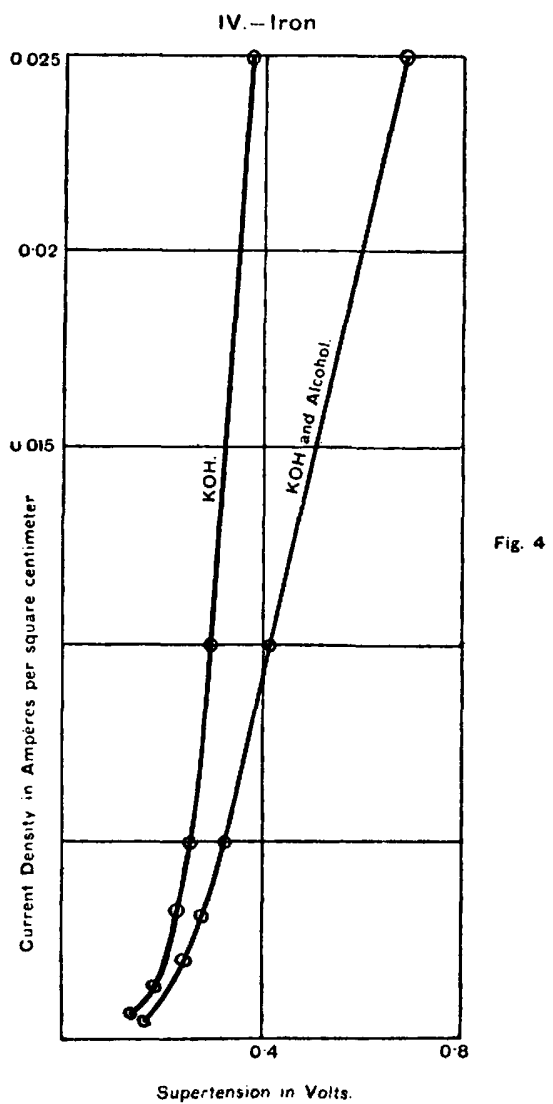

hydroxide solution, and a low value was then obtained (4). On the addition of benzaldehyde (5) the E.M.F. rose again to the high value, but fell off as the experiment proceeded. These results show conclusively that iron exists in two forms or becomes changed on the surface. It also demonstrates the varying properties of iron. Thus a sample of zinc containing traces of iron is incapable of completely reducing arsenious oxide, due presumably to the low supertension of the iron impurity. A little iron added to a solution containing a tin cathode increases the supertension slightly. The iron in this case cannot have a supertension lower than that of tin. Further, the introduction of iron salts in small quantities to an electrolytic reduction process 
has very little effect on the reaction, but when added to the Marsh-Berzelius apparatus for estimating arsenic, a marked falling off of reducing efficiency is at once apparent.

TABLE X.

Aluminium in Sulphuric Acid.

\begin{tabular}{|c|c|c|c|c|c|}
\hline \multirow{3}{*}{$\begin{array}{c}\text { (1) } \\
\text { Current Density } \\
\text { in Amperes } \\
\text { per sq. cm. }\end{array}$} & \multicolumn{5}{|c|}{ E.M.F. IN VolTS. } \\
\hline & (a) & (5) & (6) & (7) & (8) \\
\hline & $5 \% \mathrm{H}_{2} \mathrm{SO}_{4}$ & $\begin{array}{r}5 \% \mathrm{H}_{2} \mathrm{SO}_{4} \\
50 \% \text { Alcohol. } \\
0.0008 \mathrm{gm} . \mathrm{PtCl}_{4}\end{array}$ & $\begin{array}{r}5 \% \mathrm{H}_{2} \mathrm{SO}_{4} \\
50 \% \% \mathrm{Alcohol} \\
6.6 \% \mathrm{C}_{6} \mathrm{H}_{5} \mathrm{CHO} .\end{array}$ & $\begin{array}{r}5 \% \\
50 \% \text { Alcohol. }\end{array}$ & $\begin{array}{r}5 \% \mathrm{H}_{2} \mathrm{SO}_{4} \\
50 \% \% \mathrm{Allohol} \\
6.6 \% \mathrm{C}_{6} \mathrm{H}_{5} \mathrm{CHO} .\end{array}$ \\
\hline $0 \cdot 0005$ & $0^{\circ} 4942$ & - & $0^{\circ} 5^{8} 30$ & 0.4564 & 0.4681 \\
\hline 0.0007 & 0.5125 & - & 0.5975 & 0.4711 & 0.4817 \\
\hline $0^{\circ} 001$ & $0 \cdot 5283$ & 0.0447 & 0.6 III & 0.4841 & 0.4936 \\
\hline 0.0015 & 0.5464 & - & 0.6290 & 0.4995 & 0.5043 \\
\hline 0.003 & ד & 0.0758 & 0.6665 & 0.5165 & 0.5204 \\
\hline 0.005 & 0.5894 & 0.0988 & 0.7000 & 0.5404 & 0.5312 \\
\hline O.OI & 0.6155 & 0.1465 & o.7595 & 0.5618 & 0.5444 \\
\hline 0.025 & 0.6537 & 0.2731 & 0.8816 & 0.5894 & 0.5644 \\
\hline 0.05 & 0.6917 & 0.4400 & $0^{\circ} 9290$ & 0.6514 & 0.5832 \\
\hline
\end{tabular}

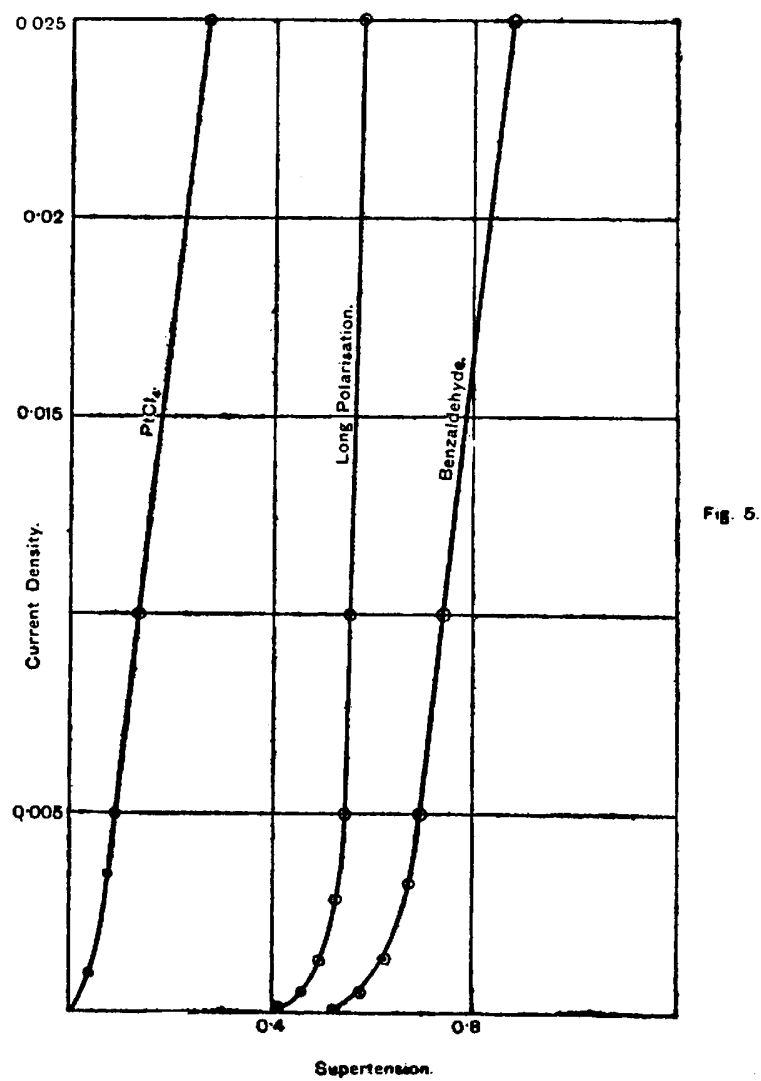


Aluminium in Sulphuric Acid.-This metal behaves like iron. A new electrode invariably causes the production of tarry matter with benzaldehyde, but at other times behaves like a metal of low supertension.

As in the case of iron, the supertension rose rapidly, but began to decrease at the higher current densities (3). On repetition with the same electrode a similar phenomenon was observed, as was also the case on exposing the metal overnight (3). A new electrode was now used, and the measurements were redetermined with the addition of alcohol; the result differed only slightly from the previous ones (4). A new solution was now made containing benzaldehyde, and the E.M.F. rose to the high value given in 6 . The same electrode was carefully washed and allowed to stand overnight and the E.M.F. redetermined (7). In this case the supertension was low, and on the addition of benzaldehyde no repetition of the previous phenomenon was shown (8). The resin produced was also small in quantity, but was the main product in the previous case. The question now arises as to the cause of this fall in the E.M.F. In experiment 5, therefore, platinum chloride was introduced into the cathode solution, but relatively large amounts were required to produce any considerable change in the supertension. It is probable, therefore, that this action is caused by a change of the metallic surface of the cathode and not to added impurities.

Zinc in Potassium Hydroxide.--It is of the greatest importance that the supertension of this metal should be determined. It is almost invariably used for the detection and estimation of small quantities of arsenic, but it gives results which vary very considerably when different samples are employed.

TABLE XI.

Zinc in Potassium Hydroxide.

\begin{tabular}{|c|c|c|c|c|}
\hline & \multicolumn{4}{|c|}{ E.M.F. IN VoLTS. } \\
\hline (1) & (2) & (3) & (द) & (5) \\
\hline $\begin{array}{l}\text { Current Density } \\
\text { in Amperes } \\
\text { per sq. cm. }\end{array}$ & $\begin{array}{c}5 \% \text { KOH. } \\
50 \% \text { Alcohol. }\end{array}$ & $\begin{array}{c}5 \% \text { KOH. } \\
50 \% \text { Alcohol. } \\
\text { o'01 gm. FeSO } \\
\text {. }\end{array}$ & $\begin{array}{l}5 \% \text { KOH. } \\
50 \% \text { Alcohol. } \\
\text { o.or gm. CuSO } \\
4 .\end{array}$ & $\begin{array}{c}5 \% \text { KOH. } \\
50 \% \text { Alcohol. } \\
0.0002 \text { gm. PtCl }\end{array}$ \\
\hline $0^{\circ} 0003$ & 0.7016 & 0.6449 & $0^{\circ} 575^{2}$ & 0.4827 \\
\hline 0.0007 & 07548 & 0.7102 & 0.6136 & $0^{\circ} 5135$ \\
\hline 0.002 & 0.8649 & - & - & - \\
\hline o.003 & 0.9142 & $0 \cdot 8763$ & 0.6917 & $0^{*} 5^{81 \text { II }}$ \\
\hline 0.007 & $098 \mathrm{I} 8$ & $0^{\circ} 947^{2}$ & 0.797 & 0.6204 \\
\hline o.017 & I'o800 & $\mathrm{r} \cdot 0348$ & $0.764 \mathrm{I}$ & $0^{\circ} 7123$ \\
\hline 0.033 & $I \cdot I 620$ & I'IO33 & $0.83 I_{5}$ & 0.8327 \\
\hline
\end{tabular}

The supertension of this metal in a pure state is very high (2), and the addition of metallic impurities lowers this value very considerably $(3,4,5)$. Thus a small quantity of copper or platinum causes a fall in potential equal to about 0.3 volt (4). The addition of iron had no marked effect, but this might have been due to the precipitation of the hydroxide of iron. In any case iron can take the part of a metal of high supertension.

Cadmium in Potassium Hydroxide.-As cadmium is related to zinc, it is probable that the two metals will be closely allied. It is of greatest importance that its relation to zinc should be determined, for it has been shown 


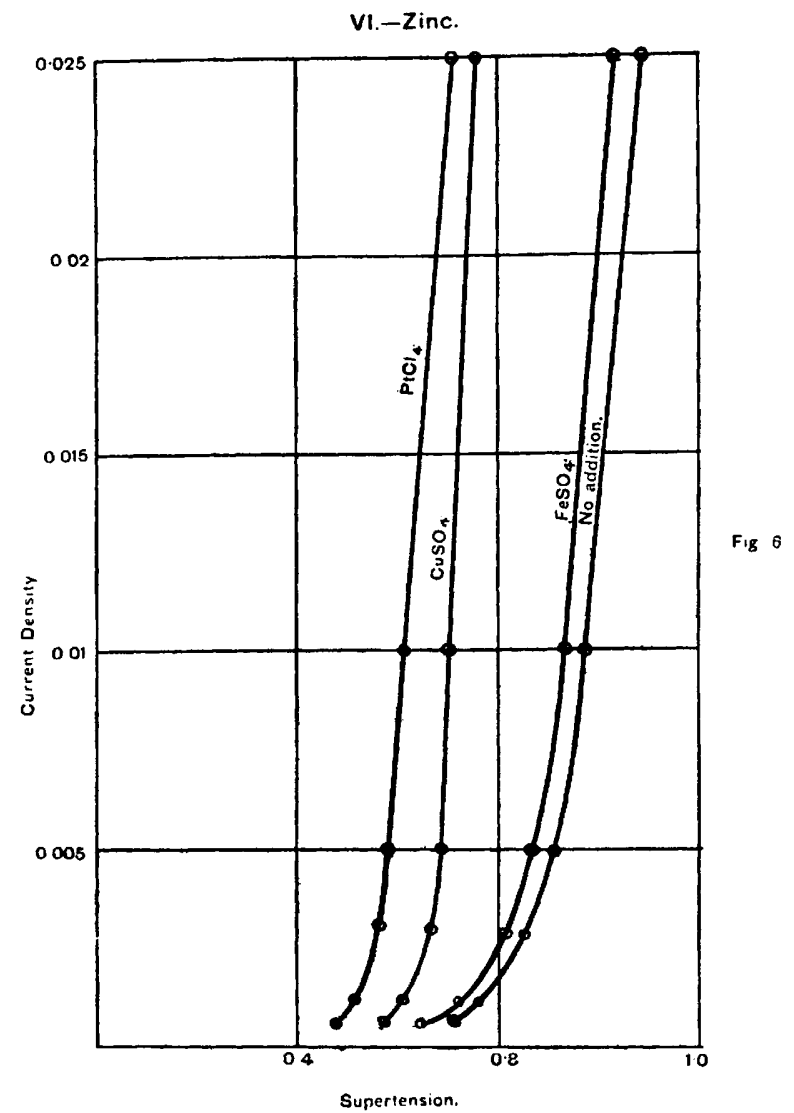

TABLE XII.

Cadmium in Potassium Hydroxide.

\begin{tabular}{|c|c|c|c|c|}
\hline \multirow{3}{*}{$\begin{array}{c}\text { (1) } \\
\text { Current Density } \\
\text { in Amperes } \\
\text { per sq. cm. }\end{array}$} & \multicolumn{3}{|c|}{ E.M.F. IN VoLTS. } & \multirow{3}{*}{$\begin{array}{c}\text { (6) } \\
5 \% \mathrm{H}_{2} \mathrm{SO}_{4} .\end{array}$} \\
\hline & (2) & (4) & (5) & \\
\hline & $5 \% \mathrm{KOH}$. & $\begin{array}{c}5 \% \% \mathrm{KOH} \\
50 \% \text { Alcohul. } \\
6.6 \% \\
\% \mathrm{C}_{6} \mathrm{H}_{5} \mathrm{CHO} \text {. }\end{array}$ & $\begin{array}{c}5 \% \text { KOH. } \\
50 \% \text { Alcohol. } \\
\text { 0.0002 gm. PtCl }\end{array}$ & \\
\hline 0.0005 & 0.5227 & 0.1090 & $0 \times 3343$ & $0^{\circ} 43^{20}$ \\
\hline 0.001 & 0.5569 & 0.2137 & 0.3850 & 0.4723 \\
\hline 0.0015 & 0.5744 & 0.2342 & - & - \\
\hline 0.003 & 0.6232 & 0.2596 & - & 0.5149 \\
\hline 0.005 & 0.7252 & 0.2850 & 0.4693 & 0.5325 \\
\hline O०Or & 0.7702 & 0.3854 & 0.4964 & 0.5539 \\
\hline 0.025 & 0.8244 & 0.5810 & 0.5425 & 0.5895 \\
\hline 0.05 & 0.8845 & 0.6961 & 0.5862 & 0.6304 \\
\hline
\end{tabular}


quite recently that when the latter metal is behaving anomalously as a reducing agent a coat of cadmium will adjust matters.

It has been noticed, however (Law and Chapman, Analyst), that zinc must be very carefully coated with cadmium before the full reducing efficiency of the former metal is recovered. In experiment 2, therefore, cadmium was deposited on platinum to the thickness of $0.5 \mathrm{~mm}$. and the E.M.F. determined. The surface was crystalline and the whole mass fairly pliable.

It will be seen from this that the supertension is considerably lower than that of zinc. This, however, is due to the influence of the platinum. It may be assumed that this latter metal is not completely covered, and the action is the same as that of adding platinum chloride to the cathode solution. That the whole mass is behaving as a metal of low supertension is quite obvious from the experiment, in which the resin formation was small (4). These experiments throw a great deal of light on the method of manipulating the MarshBerzelius test for small traces of arsenic. It is quite evident that all particles of low supertension must be entirely covered before complete reduction can take place. The addition of alcohol caused a considerable fall of potential, but this began to rise immediately to a value which on long polarisation was equal to that obtained before. Platinum behaves the same as in other cases.

Cadmium in Sulphuric Acid.-A fresh electrode was prepared, and the E.M.F. was even lower than in the previous case, but the coat was far more crystalline, which accounts for the discrepancy.

Experiment 6 gives the result for deposited cadmium which is practically the same as with platinum alone, although apparently a complete envelope had been prepared.

In the next experiment a sheet of pure cadmium, was used, and the supertension was practically the same as that of pure zinc. From this it may be inferred that the reducing power of both metals in a pure state is identical. It is difficult, however, to obtain commercial zinc free from metallic impurities, while the salts of cadmium may be easily purified by crystallisation. For all reduction purposes, therefore, it is useless to waste time in obtaining pure zinc, for this metal may be readily coated, either chemically or electrically, with pure cadmium, and more concordant results obtained. The metal, like others showing a high supertension, is very readily affected by small traces of platinum.

Lead in Potassium Hydroxide.-These results agree closely with those given by Tafel for sulphuric acid solutions.

The electrodes were very carefully prepared from pure lead by alternately oxidising and reducing the metal; they were then allowed to stand in contact with the alkali for some hours. If the readings, however, were taken immediately after preparation, the results were much lower than expected. This agrees with the results for tin. The introduction of alcohol lowers the potential somewhat. Platinum has a fairly marked effect, but its action was by no means permanent. The action of benzaldehyde was also fairly marked. With commercial lead prepared in the above manner the differences between the results obtained immediately after the introduction into the alkali and those on long standing in the cathode cell were more noticeable than above. The differences were regularly between 0.2 and 0.3 volt. The results agreed closely with those obtained by Tafel in acid solution.

Lead in Sulphuric Acid.-Commercial lead was used in this case, and the results were taken immediately after the introduction into the cathode solution. 
LIBERATED FROM METALLIC SURFACES

TABLE XIII.

Lead in Sulphuric Acid.

\begin{tabular}{|c|c|c|c|}
\hline \multirow{3}{*}{$\begin{array}{l}\text { (1) } \\
\text { Current Density } \\
\text { in Amperes } \\
\text { per sq. inch. }\end{array}$} & \multicolumn{3}{|c|}{ E.M.F. IN VoLTS. } \\
\hline & (8) & (8) & (\$) \\
\hline & $5 \% \mathrm{H}_{2} \mathrm{SO}_{4}$ & $\begin{array}{r}5 \% \underset{\mathrm{H}_{2} \mathrm{SO}_{4}}{\mathrm{H}^{2}} \text { \% Alcohol. }\end{array}$ & $\begin{array}{r}5 \% \mathrm{H}_{2} \mathrm{SO}_{4} \\
50 \% \mathrm{Alcohol} \\
6.6 \% \mathrm{C}_{6} \mathrm{H}_{5} \mathrm{CHO} .\end{array}$ \\
\hline 0.0005 & 0.5701 & 0.5260 & 0.4059 \\
\hline 0.0009 & 0.6028 & 0.5585 & 0.4234 \\
\hline $0^{\circ} \mathrm{OOI}$ & $0^{\circ} 6078$ & 0.5637 & 0.4259 \\
\hline 0.0015 & 0.6297 & 0.5825 & $0: 4377$ \\
\hline 0.003 & 0.6633 & 0.6137 & 0.4469 \\
\hline 0.005 & 0.6873 & 0.6340 & 0.4545 \\
\hline O०OI & 0.7038 & 0.6621 & 0.4669 \\
\hline 0.05 & 0.7427 & 0.7361 & 0.5394 \\
\hline
\end{tabular}

It will be seen immediately that these readings are much lower than those obtained by Tafel for pure lead. On being left to stand overnight in acid solution these values increased and approached those of the pure metal.

Amalgamated Metals.-Amalgamated lead $(2,3)$ gave values slightly below those of mercury, but this may have been due to the absence of the curious increase of potential observed with the latter metal. With zinc, however,

TABLE XIV.

Amalgamated Metals.

\begin{tabular}{|c|c|c|c|c|c|}
\hline \multirow[b]{2}{*}{$\begin{array}{c}\text { (1) } \\
\text { Current Density } \\
\text { in Amperes } \\
\text { per sq. cm. }\end{array}$} & \multicolumn{5}{|c|}{ E.M.F. IN VolTs, } \\
\hline & $\begin{array}{c}\text { (2) } \\
\text { Lead. } \\
5 \% \text { KOH. } \\
50 \% \text { Alcohol. }\end{array}$ & $\begin{array}{c}\text { (8) } \\
\text { Lead. } \\
5 \% \mathrm{H}_{2} \mathrm{SO}_{4} \\
50 \% \text { Alcohol. }\end{array}$ & $\begin{array}{c}\text { (4) } \\
\text { Zinc. } \\
5 \% \text { KOH. } \\
50 \% \text { Alcohol. }\end{array}$ & $\begin{array}{c}\text { (5) } \\
\text { Zinc. } \\
5 \% \text { KoH. } \\
5 \% \text { Alcohol. } \\
\text { 0.002 } \mathrm{gm} . \mathrm{PtCl}_{4} \text {. }\end{array}$ & $\begin{array}{c}\text { (6) } \\
\text { Zinc. } \\
5 \% \mathrm{H}_{2} \mathrm{SO}_{4} \\
50 \% \text { Alcohol. }\end{array}$ \\
\hline $\begin{array}{l}0.0005 \\
0.001 \\
0.003 \\
0.005 \\
0.01 \\
0.025 \\
0.05\end{array}$ & $\begin{array}{l}0^{\circ} 7127 \\
0.8055 \\
0.9101 \\
0.9544 \\
\text { r.00I2 } \\
\text { I.0270 } \\
\text { I.0687 }\end{array}$ & $\begin{array}{l}0^{\circ} 7070 \\
0^{\circ} 7485 \\
0.7997 \\
0.8210 \\
0.8756 \\
0.9420 \\
0^{\circ} 0327\end{array}$ & $\begin{array}{c}0.9365 \\
0 \cdot 9621 \\
0 \cdot 9851 \\
0 \cdot 9973 \\
\overline{1}-1632 \\
r \cdot 2495\end{array}$ & $\begin{array}{c}0.6145 \\
0.6521 \\
0.8082 \\
0.9031 \\
0.9980 \\
\frac{1085}{x}\end{array}$ & $\begin{array}{c}0 \cdot 8626 \\
0 \cdot 9536 \\
0 \cdot 9748 \\
\text { I'0045 } \\
- \\
\text { I'2r } 94 \\
I \cdot 3799\end{array}$ \\
\hline
\end{tabular}

the values were quite as high as those of mercury alone, this combination behaving in all respects like mercury $(4,6)$. The action of platinum is very curious in the case of lead.

The introduction of $0^{\circ} 0002$ gram of platinum chloride produced a slight increase of E.M.F. in potassium hydroxide solutions. With $0^{\circ}$.oor gram a very small fall was observ $d$, but with o'or gram a very considerable change 
was produced, a result very little higher than that with platinised platinum being registered. In acid solutions the introduction of $0^{\circ} 002$ platinum chloride produced an immediate fall of potential amounting to $0^{\circ} \mathrm{I}$ volt. The same quantity of platinum chloride produced the same drop for zinc in both acid and alkaline solutions (5). Very small quantities of platinum chloride had, however, scarcely any effect on the supertension.

Mercury.-The results obtained with this substance were much higher than was expected. This is probably due to the formation of a hydrogen film. Even on largely increasing the surface of the metal this film per. sisted. Violent agitation would break it down altogether. The result was practically the same as that of amalgamated zinc in potassium hydroxide (experiment 4). 